\title{
PERBEDAAN EFEKTIFITAS RETENSI DAN PREVENTIF KARIES BAHAN PIT DAN FISSURE SEALANT
}

Hesti Witasari JE*, Agus Ardinansyah**

Keywords:

GIC, permanent molars, pit and fissure sealants, resin-based sealants

\begin{abstract}
Introduction: Dental caries is a fairly high dental disease that occurs in most countries, which is approximately 60-90\% occur in children. Pit and Fissure sealants are materials that are placed on pits and dental fissures that aim to prevent dental caries. There are several types of materials which often used as pit and sealant fissures, including Glass lonomer Cement (GIC) and Resinbased Sealant/Composite Resin (RK). The purpose of this study is analising the differences in the effectiveness of retention and prevention of caries in GIC and $R K$ pit and fissure sealants in elementary school children.

Method: The subjects are 76 permanent teeth of 7-8 years old children with a grouping of 38 teeth each based on the material tested of GIC and RK. Results: There is a significant differences between the pit and fissure sealant material of GIC and RK in the effectiveness of retention and prevention of caries.

Conclusion: In the statistical calculation, the comparative effectiveness of retention and caries prevention pit and fissure sealant RK and GIC materials is significant difference. The RK material is more effective in retention and prevention of caries compared with GIC.
\end{abstract}

\section{PENDAHULUAN}

Penyakit karies gigi merupakan penyakit gigi yang cukup tinggi terjadi di kebanyak negara baik negara berkembang mau pun negara industri, yaitu kurang lebih $60-90 \%$ terjadi pada anakanak. Berdasarkan Riset Kesehatan Dasar (RISKESDAS) tahun 2013 menunjukkan prevalensi karies aktif kelompok umur 12 tahun 2013 sebesar 42,6\% dan angka pengalaman karies sebesar $50,2 \%$ dengan rata-rata DMF-T sebesar 1,4.Angka ini telah mengalami kenaikan yang cukup signifikan jika dibandingkan dengan data tahun 2007 yaitu karies aktif sebesar 28,8\%, angka pengalaman karies sebesar $36,1 \%$ dan rerata DMF-T sebesar 0,91. ${ }^{1}$ Karies merupakan kehilangan ion mineral kronis berlanjut pada email mahkota maupun permukaan akar yang disebabkan oleh flora bacterial dan produkproduknya. Kehilangan mineral dini hanya dapat terlihat secara mikroskopis namun seringkali pada email terlihat sebagai lesi "white spot" (bercak putih) atau pada akar berupa perlunakan sementum. Kegagalan untuk mengkompensasi kehilangan mineral tersebut akan menimbulkan kavitasi yang dapat berlanjut terus hingga menyebabkan kerusakan ireversibel pada pulpa. ${ }^{2}$

Bagian Konservasi Gigi Fakultas Kedokteran Gigi Universitas YARSI

Bagian Pendidikan Kedokteran Gigi Fakultas Kedokteran Gigi Universitas YARSI

Korespondensi: hesti.witasari@yarsi.ac.id 
Struktur anatomis gigi juga berperan penting dalam pembentukan karies. Permukaan gigi yang rentan karies adalah permukaan yang mudah mengalami retensi plak dan sulit dibersihkan. Salah satu daerah gigi tersebut yaitu pit dan fisur permukaan oklusal gigi posterior. Gigi Molar satu rahang bawah merupakan gigi permanen pertama yang tumbuh pada usia kurang lebih 6-9 tahun. Gambaran anatomi gigi molar satu rahang bawah ini memiliki pit dan fisur yang mayoritas dalam sehingga sangat rentan terhadap retensi plak dan sisa makanan, yang mana dapat membantu suburnya pertumbuhan bakteri pada area tersebut. ${ }^{3}$ Dalam bidang kedokteran gigi, Intervensi minimal adalah suatu filosofi atau konsep dasar perawatan profesional yang fokus terhadap resiko, deteksi awal, dan perawatan penyakit sedini mungkin pada tingkat mikro, diikuti dengan perawatan yang paling minimal dan nyaman bagi pasien untuk memperbaiki kerusakan ireversibel pada gigi yang diakibatkan oleh penyakit. Salah satu tindakan preventif penyakit karies yaitu melakukan aplikasi pit and fissure sealant pada gigi posterior yang masih bebas karies. ${ }^{4}$

Pit and Fissure sealant merupakan bahan yang diletakkan pada pit dan fisura gigi yang bertujuan untuk mencegah proses karies gigi. Bentuk pit dan fisura beragam, akan tetapi bentuk umumnya adalah sempit, melipat dan tidak teratur. Bakteri dan sisa makanan menumpuk di daerah tersebut. Saliva dan alat pembersih mekanis sulit menjangkaunya. Dengan diberikannya bahan penutup pit dan fisura pada awal erupsi gigi, diharapkan dapat mencegah bakteri sisa makanan berada dalam pit dan fisura. ${ }^{5}$

Pada masalah penyakit karies yang ditemukan berdasarkan data di atas, dapat disebabkan oleh kurangnya keinginan masyarakat untuk memeriksakan giginya secara berkala ke dokter gigi agar dapat dilakukan tindakan preventif terhadap penyakit karies. Untuk itu perlu dilakukan suatu tindakan preventif yang dapat mengurangi tingkat prevalensi penyakit karies berupa penutupan pit dan fisur (pit and fissure sealent) gigi posterior pada anakanak. Namun yang sering menjadi kendala pada penggunaan bahan yang diaplikasikan untuk pit and fissure sealant ini yaitu kurangnya retensi pada gigi anak karena berbagai faktor sehingga tidak bertahan lama bahkan mudah sekali hilang. Hal ini dapat menyebabkan karies mudah terjadi di area oklusal gigi permanen tersebut. ${ }^{5}$

Menurut Sukanto (2017),bahan sealant yang ideal adalah bahan mempunyai kemampuan retensi yang tahan lama, kelarutan terhadap cairan mulut rendah, biokompatibel dengan jaringan rongga mulut, dan mudah diaplikasikan. Ada beberapa macam bahan yang sering digunakan sebagai pit and fissure sealent, yaitu diantaranya bahan Glass lonomer cement (GIC) dan bahan berbasis resin atau Resin komposit (RK). ${ }^{3}$ Pada bahan-bahan ini dikatakan bahwa GIC memiliki efek fluoridasi sehingga diharapkan dapat lebih baik untuk mencegah terjadinya karies, namun memiliki retensi yang lebih rendah dibanding resin-based sealant. ${ }^{6}$ Pada penelitian lain dikatakan bahwa GIC dan Resin-based 


\begin{abstract}
Sealant/Resin Komposit(RK) tidak terjadi peningkatan karies yang berarti setelah dievaluasi selama 6 bulan. Dan dikatakan juga bahwa resin-based sealant lebih retentif dibandingkan dengan bahan GIC. ${ }^{7}$ Tujuan utama penelitian ini untuk mengetahui perbedaan efektivitas retensi dan preventif karies pada bahan pit and fissure sealantGlass lonomer Cement (GIC) dan Resin-based Sealant/Resin Komposit(RK) pada anak Sekolah Dasar. Hal ini disebabkan, pada anak-anak ini terdapat gigi permanen yang baru erupsi sehingga belum terjadi karies.
\end{abstract}

\section{METODE PENELITIAN}

Penelitian ini telah lolos kelayakan etik penelitian di Universitas YARSI dengan nomor No. Etik: 030/KEP-UY/BIA/IV/2019. Jenis penelitian ini merupakan penelitian eksperimentalanalitik dengan metode kuantitatif. Rancangan penelitian yang di gunakan adalah kohort karena dievaluasi kembali setelah 6 bulan kemudian. Populasi penelitian ini adalah siswasiswi kelas 2 SD Negeri 12 Sumur Batu, Kelurahan Sumur Batu, Kecamatan Kemayoran, Jakarta Pusat. Kriteria inklusi adalah siswa-siswi yang sudah erupsi gigi molar permanennya dan bersedia untuk dilakukan tindakan pencegahan pit and fissure sealant. Kriteria ekslusi adalah siswa-siswi yang gigi molar permanennya belum erupsi, dan yang sudah terdapat karies pada pit dan fisuranya. Sampel penelitian adalah gigi molar permanen pada siswa-siswi SD Negeri 12 Sumur Batu, Jakarta Pusat. Dengan penetapan besar sampel didapat dari jumlah orang dikali jumlah gigi yang di teliti. Bahan pit and fissure sealant yang baik adalah bahan yang dapat mengisi celah pit dan fisura gigi dengan baik, memiliki daya alir yang optimal, dan memiliki waktu setting yang cepat, serta mampu bertahan lama di dalam area tersebut, sehingga diperoleh retensi yang baik untuk mencegah masuknya sisa makanan di area tersebut dan mencegah terjadinya karies pada gigi tersebut. Pengukuran retensi material ditentukan dengan sistem ukur skor yaitu 0 tidak ada, 1 ada sebagian, 2 masih lengkap/utuh. Sedangkan pengukuran preventif karies dengan melihat ada atau tidaknya karies.

Siswa-siswi kelas 2 dilakukan screening terlebih dahulu. Kegiatan screening yaitu mengidentifikasi peserta yang bisa dilakukan penutupan pit dan fisura. Penutupan pit dan fisura dilakukan untuk gigi molar satu bawah yang baru erupsi dan tidak mengalami karies. Penutupan dimaksudkan untuk mencegah terjadinya karies. Setelah itu anak-anak dilakukan aplikasi pit and fissure sealant pada gigi molar permanen rahang bawah. Pada masing-masing rahang diaplikasikan bahan GIC pada gigi molar permanen sebelah kanan, dan bahan RK pada sebelah kiri. Setelah 6 bulan kemudian sampel dievaluasi kembali dan dilakukan pencatatan data. Total jumlah siswa ada 59 orang, dengan gigi yang diperiksa sebanyak 118 gigi molar satu permanen rahang bawah kanan dan kiri.Total siswa eksklusi ada 21 anak atau 42 gigi karena gigi sudah berlubang besar, dan yang masuk kriteria inclusi 38 anak atau 76 gigi. 38 gigi molar satu kanan rahang bawah dilakukan pit and fissure sealant dengan bahan RK, dan 38 gigi molar satu kiri rahang bawah dilakukan pit and 
fissure sealant dengan menggunakan bahan GIC.Setelah gigi dilakukan pit and fissure sealant, siswa diinstruksikan untuk tidak makan selama 1 jam. Kemudian, evaluasi dilakukan setelah 6 bulan, dengan memeriksa kembali semua gigi yang telah dilakukan pit and fissure sealant. Masing-masing gigi akan dievaluasi keadaan bahan tersebut dan ada/tidaknya karies di area oklusal gigi tersebut dengan pengukuran yang telah dijelas diatas. Uji statistik yang dilakukan adalah uji beda dengan menggunakan Chisquare. Nilai minimum yang dianggap bermakna jika $p<0,05$.

\section{HASIL PENELITIAN}

Berdasar penelitian yang telah dilakukan, maka didapatkan hasil berupa perhitungan frekuensi dari masing-masing kelompok dan didapatkan pula hasil perhitungan dengan statistik. Total jumlah siswa yang ada 59 orang, dengan gigi yang diperiksa sebanyak 118 gigi molar satu permanen rahang bawah kanan dan kiri. Total siswa exclusi ada 21 anak atau 42 gigi karena gigi sudah berlubang besar, dan yang masuk kriteria inclusi sebanyak 38 anak atau 76 gigi. 38 gigi molar satu kanan rahang bawah dilakukan pit and fissure sealant dengan bahan resin komposit, dan 38 gigi molar satu kiri rahang bawah dilakukan pit and fissure sealant dengan menggunakan bahan Glass lonomer Cement.
Tabel 1. Hasil perhitungan frekuensi pit and fissure sealant dengan menggunakan bahan Glass lonomer Cement (GIC)

\begin{tabular}{lcccc}
\hline \multicolumn{5}{c}{ GIC } \\
& Frequency & Percent & Valid \\
Percent & $\begin{array}{c}\text { Cumulative } \\
\text { Percent }\end{array}$ \\
\hline Utuh & 3 & 7.9 & 7.9 & 7.9 \\
\hline Sebagian & 9 & 23.7 & 23.7 & 31.6 \\
\hline Tidak & 26 & 68.4 & 68.4 & 100.0 \\
ada & & & & \\
\hline Total & 38 & 100.0 & 100.0 & \\
\hline
\end{tabular}

Dari table diatas, dapat diketahui persentase kelompok GIC yang pit and fissure sealant masih utuh, sisa sebagian, dan tidak ada sisa sedikit pun. Persentase terbesar adalah bahan GIC yang sudah tidak tersisa lagi yaitu $68,4 \%$.Sedangkan persentase terkecil adalah yang pit and fissure sealant masih utuh yaitu sebanyak $7,9 \%$.

Tabel 2. Hasil perhitungan frekuensi karies pada kelompok pit and fissure sealant dengan menggunakan bahan Glass lonomer Cement (GIC)

\begin{tabular}{cccc}
\hline Frequency & Percent & Valid Percent & $\begin{array}{c}\text { Cumulative } \\
\text { Percent }\end{array}$ \\
\hline 29 & 76.3 & 76.3 & 76.3 \\
\hline 9 & 23.7 & 23.7 & 100.0 \\
\hline 38 & 100.0 & 100.0 & \\
\hline
\end{tabular}


Tabel 3. Hasil perhitungan frekuensi pit and fissure sealant dengan menggunakan bahan Resin Komposit (RK)

\begin{tabular}{|c|c|c|c|c|}
\hline \multicolumn{5}{|c|}{ RK } \\
\hline & Frequency & Percent & Valid Percent & $\begin{array}{c}\text { Cumulative } \\
\text { Percent }\end{array}$ \\
\hline utuh & 6 & 15.8 & 15.8 & 15.8 \\
\hline sebagian & 11 & 28.9 & 28.9 & 44.7 \\
\hline $\begin{array}{l}\text { tidak ada } \\
\text { tambalan }\end{array}$ & 21 & 55.3 & 55.3 & 100.0 \\
\hline Total & 38 & 100.0 & 100.0 & \\
\hline
\end{tabular}

Dari hasil tabel 3, diketahui persentase pit and fissure sealant dengan menggunakan bahan Resin Komposit (RK) yang terbesar adalah kelompok RK yang sudah tidak ada bahannya yaitu sebesar 55,3\%.Sedangkan persentase terkecil yaitu kelompok yang masih utuh yaitu sebesar $15,8 \%$.

Tabel 4. Hasil perhitungan frekuensi karies pada kelompok pit and fissure sealant dengan menggunakan bahan Resin Komposit (RK)

\begin{tabular}{lcccc}
\hline \multicolumn{5}{c}{ RK dengan pemeriksaan karies } \\
\hline & Frequency & Percent & $\begin{array}{c}\text { Valid } \\
\text { Percent }\end{array}$ & $\begin{array}{c}\text { Cumulative } \\
\text { Percent }\end{array}$ \\
\hline $\begin{array}{l}\text { Tidak } \\
\text { karies }\end{array}$ & 32 & 84.2 & 84.2 & 84.2 \\
\hline Karies & 6 & 15.8 & 15.8 & 100.0 \\
\hline Total & 38 & 100.0 & 100.0 &
\end{tabular}

Hasil dari tabel 4, diketahui persentase terbesar untuk pemeriksaan karies bahan RK yaitu kelompok tidak ada karies yaitu sebesar $84,2 \%$.Sedangkan kelompok ada karies hanya sebesar $15,8 \%$.

Tabel 5. Hasil perhitungan perbandingan karies antara pit and fissure sealant bahan GIC dan bahan RK

\begin{tabular}{|c|c|c|c|c|}
\hline \multicolumn{5}{|c|}{ Perbandingan karies GIC dan RK } \\
\hline & & \multicolumn{2}{|c|}{ RK_karies } & \multirow[b]{2}{*}{ Total } \\
\hline & & ada karies & $\begin{array}{c}\text { tidak ada } \\
\text { karies }\end{array}$ & \\
\hline \multirow{4}{*}{ gic_karies } & Count & 5 & 4 & 9 \\
\hline & $\begin{array}{r}\text { karies } \% \text { within } \\
\text { gic_karies }\end{array}$ & $55.6 \%$ & $44.4 \%$ & $100.0 \%$ \\
\hline & Count & 1 & 28 & 29 \\
\hline & $\begin{array}{c}\text { karies } \\
\text { gic_karies }\end{array}$ & $3.4 \%$ & $96.6 \%$ & $100.0 \%$ \\
\hline \multirow[b]{2}{*}{ Total } & Count & 6 & 32 & 38 \\
\hline & $\begin{array}{l}\text { \% within } \\
\text { gic_karies }\end{array}$ & $15.8 \%$ & $84.2 \%$ & $100.0 \%$ \\
\hline
\end{tabular}

Tabel 6. Hasil perhitungan Chi-Square Tests.

Dari hasil tabel 5 dan 6 , dapat diketahui hubungan perbandingan pit and fissure sealant bahan GIC dan bahan RK ada perbedaan yang signifikan. $(p<0,05)$.

\begin{tabular}{|c|c|c|c|c|c|}
\hline \multicolumn{6}{|c|}{ Chi-Square Tests } \\
\hline & Value & df & $\begin{array}{l}\text { Asymp. } \\
\text { Sig. (2- } \\
\text { sided) }\end{array}$ & $\begin{array}{l}\text { Exact } \\
\text { Sig. (2- } \\
\text { sided) }\end{array}$ & $\begin{array}{c}\text { Exact Sig. } \\
\text { (1-sided) }\end{array}$ \\
\hline $\begin{array}{l}\text { Pearson } \\
\text { Chi-Square }\end{array}$ & $14.026^{a}$ & $\overline{1}$ & $\overline{0}$ & & \\
\hline $\begin{array}{l}\text { Continuity } \\
\text { Correction }^{\mathrm{b}}\end{array}$ & 10.38 & 1 & 0.001 & & \\
\hline $\begin{array}{l}\text { Likelihood } \\
\text { Ratio }\end{array}$ & 12.083 & 1 & 0.001 & & \\
\hline $\begin{array}{l}\text { Fisher's } \\
\text { Exact Test }\end{array}$ & & & & 0.001 & 0.001 \\
\hline $\begin{array}{l}\text { Linear-by- } \\
\text { Linear } \\
\text { Association }\end{array}$ & 13.656 & 1 & 0 & & \\
\hline $\begin{array}{l}\mathrm{N} \text { of Valid } \\
\text { Cases }\end{array}$ & 38 & & & & \\
\hline
\end{tabular}




\section{DISKUSI}

Penelitian ini dilakukan untuk mengetahui perbedaan efektivitas retensi dan preventif karies pada bahan pit and fissure sealantGlass lonomer Cement (GIC) danResin-based Sealant/Resin Komposit (RK) pada anak Sekolah Dasar. Pada penelitian ini menggunakan sampel siswa dan siswi SD kelas 2 dengan tujuan mendapatkan sampel anak-anak berusia kurang lebih 7-8 tahun, karena pada usia tersebut gigi Molar satu rahang bawah sudah erupsi dengan waktu yang belum lama, sehingga didapatkan keadaan gigi yang masih bebas karies.Hal ini disebabkan, pada anak-anak ini terdapat gigi permanen yang baru erupsi sehingga belum terjadi karies.Bahan sealant yang ideal adalah bahan mempunyai kemampuan retensi yang tahan lama, kelarutan terhadap cairan mulut rendah, biokompatibel dengan jaringan rongga mulut, dan mudah diaplikasikan. Ada beberapa macam bahan yang sering digunakan sebagai pit and fissure sealent, yaitu diantaranya bahan Glass lonomer cement (GIC) dan bahan berbasis resin atau Resin komposit (RK).Struktur anatomis gigijuga berperan penting dalam pembentukan karies. Permukaan gigi yang rentan karies adalah permukaan yang mudah mengalami retensi plak dan sulit dibersihkan. Salah satu daerah gigi tersebut yaitu pit dan fisur permukaan oklusal gigi posterior. Gigi Molar satu rahang bawah merupakan gigi permanen pertama yang tumbuh pada usia kurang lebih 6-9 tahun. Gambaran anatomi gigi molar satu rahang bawah ini memiliki pit dan fisur yang mayoritas dalam sehingga sangat rentan terhadap retensi plak dan sisa makanan, yang mana dapat membantu suburnya pertumbuhan bakteri pada area tersebut. ${ }^{3}$

Total jumlah siswa yang ada 59 orang, dengan gigi yang diperiksa sebanyak 118 gigi molar satu permanen rahang bawah kanan dan kiri. Total siswa exclusi ada 21 anak atau 42 gigi karena gigi sudah berlubang besar, dan yang masuk kriteria inclusi sebanyak 38 anak atau 76 gigi. 38 gigi molar satu kanan rahang bawah dilakukan pit and fissure sealant dengan bahan resin komposit, dan 38 gigi molar satu kiri rahang bawah dilakukan pit and fissure sealant dengan menggunakan bahan Glass lonomer Cement. Kedua bahan ini diaplikasikasikan di rongga mulut yang sama dengan tujuan meminimalisir efek bias dari faktor lingkungan yang berbeda. Pit and fissure sealant pada penelitian ini dilakukan untuk menguji bahan material yang diaplikasikan pada gigi yang masih bebas karies tersebut, dalam hal retensi bahan dan efektifitas untuk mencegah karies.Penutupan ini perlu dilakukan karena bentuk pit dan fisura bentuk $\mathrm{V}$ atau I cenderung dalam, sempit dan berkelok sehingga lebih rentan karies. Bentuk ini mengakibatkan penumpukan plak, mikroorganisme dan debris yang sulit untuk dibersihkan. ${ }^{8}$ Indikasi pemberian sealant pada pit dan fisura adalah bentuk pit dan fisura dalam,pit dan fisura dengan dekalsifikasi minimal, karies pada pit dan fisura atau restorasi pada gigi sulung atau permanen lainnya, tidak adanya karies interproximal, kemungkinkan isolasi adekuat terhadap kontaminasi saliva, dan umur gigi erupsi kurang dari 4 tahun. ${ }^{9}$

Pada tabel frekuensi yang ada di atas, dapat diketahui persentase kelompok GIC yang 
pit and fissure sealant masih utuh, sisa sebagian, dan tidak ada sisa sedikit pun. Persentase terbesar adalah bahan GIC yang sudah tidak tersisa lagi yaitu 68,4\%.Sedangkan persentase terkecil adalah yang pit and fissure sealant masih utuh yaitu sebanyak 7,9\%.Pada keadaan ini dapat disimpulkan jumlah bahan yang masih utuh di mulut sampel jauh sangat sedikit dibandingkan dengan yang tidak tersisa lagi.Hal ini dapat disebabkan karena sampel sudah menggunakan gigi tersebut untuk mengunyah makanan sebelum waktunya keras.Dapat juga disebabkan karena sampel tidak mengkontrol jenis makanan dan minuman contohnya yang asam, sehingga dapat melarutkan GIC. Kemungkinan lainnya karena waktu setting awal bahan yang cukup lama yaitu kurang lebih 3 menit, sampel dapat melepaskan bahan tersebut dengan lidah atau dengan tangannya.Hal ini sejalan dengan penelitian yang dilakukan oleh Peter dkk(1995) yang mengatakan bahwa GIC memiliki efek fluoridasi sehingga diharapkan dapat lebih baik untuk mencegah terjadinya karies, namun memiliki retensi yang lebih rendah dibanding resin-based sealant. ${ }^{6}$

Untuk perhitungan frekuensi bahan RK, diketahui persentase pit and fissure sealant dengan menggunakan bahan Resin Komposit (RK) yang terbesar adalah kelompok RK yang sudah tidak ada bahannya yaitu sebesar $55,3 \%$.Sedangkan persentase terkecil yaitu kelompok yang masih utuh yaitu sebesar $15,8 \%$. Hasil ini mirip dengan GIC yaitu kelompok bahan yang masih utuh jauh lebih kecil dibanding dengan kelompok yang tidak utuh. Hal ini dapat disebabkan karena teknik aplikasi pit and fissure sealant RK memiliki teknik yang sensitif sehingga sebaiknya dilakukan di dental unit dengan peralatan yang menunjang misalnya dilengkapi alat penyedot saliva, sehingga pada saat aplikasi bahan permukaan gigi telah kering dengan baik.Retensi suatu bahan resin komposit dipengaruhi oleh kekuatan cairan yang disebut cairan adhesive. Cairan ini merupakan bahan bonding yang membasahi permukaan kavitas gigi dan masuk kedalam email dan dentin serta menyebar keseluruh permukaan dengan sudut kontak nol atau kecil tanpa udara atau bahan lain yang terperangkap sehingga dapat memiliki kekuatan kimia dan mekanik. Hal inilah yang menyebabkan teknik aplikasi resin komposit sangat sensitif dalam mencapai keberhasilan penggunaannya. ${ }^{10}$

Dari tabel frekuensi retensi bahan pada kedua bahan diatas dapat dibandingkan, yaitu pada kelompok persentase bahan yang tidak ada sisa, pada GIC sebanyak $68,4 \%$ dan RK sebanyak $55,3 \%$. Dan bila dibandingkan pada kelompok yang utuh, GIC sebanyak 7,9\% dan RK sebanyak 15,8\%. Hal ini dapat disimpulkan bahwa retensi RK lebih baik dibandingkan GIC, karena jumlah kelompok utuh lebih banyak dibanding GIC, dan jumlah kelompok yang tidak ada sisa lebih sedikit dibanding GIC. Namun bila diujikan signifikansinya, perbedaan retensi kedua bahan ini tidak signifikan dengan menggunakan Chi-square test.Dari tabel frekuensi karies diatas, diketahui kelompok GIC yang mengalami karies sebanyak $23,7 \%$ dan yang tidak mengalami karies sebanyak 76,3\%.Pada keadaan ini, gigi yang telah diaplikasikan bahan dilakukan observasi kembali setelah 6 bulan dan dilihat 
apakah terdapat karies atau tidak. Dan ternyata $23,7 \%$ mengalami karies, hal ini dapat disebabkan pit and fissure sealant GIC sudah lepas dari awal pemberian aplikasi, dan kemungkinan lain adalah penjagaan kebersihan gigi dan mulut yang kurang baik dari sampel tersebut.Dari tabel frekuensi karies kelompok bahan RK, diketahui persentase terbesar untuk pemeriksaan karies bahan RK yaitu kelompok tidak ada karies yaitu sebesar $84,2 \%$.Sedangkan kelompok ada karies hanya sebesar 15,8\%. Hal ini dapat disebabkan karena kemungkinan pada kelompok karies bahan telah lepas dari awal, dan juga karena penjagaan kebersihan gigi dan mulut yang kurang baik. Dari hasil yang diperoleh tersebut dapat dikatakan hasil tersebut sejalan dengan penelitian lain yang menyatakan bahwa GIC dan Resin-based Sealant/Resin Komposit(RK) tidak terjadi peningkatan karies yang berarti setelah dievaluasi selama 6 bulan. Dan dikatakan juga bahwa resin-based sealant lebih retentif dibandingkan dengan bahan GIC. ${ }^{7}$

Untuk perhitungan perbandingan karies pada kedua bahan diatas, dapat diketahui hubungan perbandingan pit and fissure sealant bahan GIC dan bahan RK ada perbedaan yang signifikan. $(p<0,05)$. Hal ini dapat dibandingkan yaitu pada kelompok yang tidak mengalami karies, kelompok RK lebih tinggi dibanding GIC yaitu sebanyak 84,2\%.Dan pada kelompok karies, kelompok RK lebih kecil dibanding GIC.Sehingga dapat disimpulkan penggunaan bahan pit and fissure sealant yang baik yaitu menggunakan bahan RK.Hal ini sejalan dengan penelitian baru-baru ini yang menguji retensi bahan resin komposit untuk pit and fissure sealant.Pada penelitian tersebut dikatakan bahwa dalam waktu 6 bulan bahan pit and fissure sealant dengan bahan resin komposit sebagian besar memiliki retensi yang masih utuh. ${ }^{11}$ Pada penelitian lain juga menyatakan bahwa kekuatan RK lebih baik dibandingkan GIC terutama dalam mendukung kekuatan struktur gigi yang tersisa. ${ }^{12}$

\section{KESIMPULAN}

Pada penelitian ini dapat disimpulkan bahwa bahan pit and fissure sealant GIC memiliki retensi yang kecil dan memiliki daya efektifitas preventif karies yang kecil pula. Dan pada bahan pit and fissure sealant resin-based atau resin komposit (RK) memiliki retensi yang besar dan memiliki daya efektifitas preventif karies yang besar pula. Bila dibandingkan antara keduanya, pada perhitungan statistik perbandingan retensi bahan pit and fissure sealant RK dan GIC didapatkan perbedaan yang tidak signifikan, namun RK memiliki retensi yang lebih tinggi disbanding GIC. Sedangkan pada perhitungan statistik perbandingan efektifitas preventif karies dengan bahan pit and fissure sealant RK dan GIC didapatkan perbedaan yang signifikan, yaitu bahan RK lebih efektif tidak menyebabkan karies dibandingkan dengan GIC.

\section{UCAPAN TERIMAKASIH}

Puji syukur kepada Allah SWT atas terwujudnya penelitian ini, serta kami ucapkan terimakasih kepada institusi kami dari universitas YARSI yang telah mendanai penelitian ini. Dan terimakasih pula pada semua pihak terkait yang tidak dapat 
kami sebut satu per satu pada semua rekan, sahabat yang telah mendukung adanya penelitian ini.

\section{DAFTAR PUSTAKA}

1. Badan Penelitian dan Pengembangan Kesehatan Kementerian Kesehatan RI (2013) RISKESDAS 2012

2. International Caries Detection and Assesment System Coordinating Committee. International Caries Detection and Assesment System (ICDAS) Criteria Manual. Baltimore USA. 2005

3. Sukanto. Pit dan fissure sealent. https://sukantodrg.files.wordpress.com/.../pitdan-fisssure-sealent-makalah-bab-1-42.d. pada 8 Maret 2017

4. Mickenautsch S, Leal SC. How to Apply Evidence-based Minimum Intervention (MI) in the Dental Practice: A 'Patient-based Learning' Guide. $1^{\text {st }}$ Ed. South Africa: Midentistry Corp. 2006.

5. Andlaw, RJ and Rock. 1992. Perawatan Gigi Anak. Alih bahasa: Agus Djaya dari A Manual of Pedodontics. Jakarta: EGC

6. Peter A., Paul JR., Retention and caries preventive effects of a GIC and a resin-based fissure sealant. Community Dent Oral Epidemiol; 1995:23:282-5

7. Songpaisan $Y$, Bratthal D, Phantumvanit $P$, Somridhivej Y.Effects of glass ionomer cement, resin-based pit and fissure sealant and HF applications on occlusal caries in a developing country field trial. Community Dent Oral Epidemiol 1995; 23: 25-9
8. Anusavice, Kenneth J. 1994. Ilmu Bahan Kedokteran Gigi. Jakarta: EGC

9. Ganesh, Mahadevan MDS, et al. 2007. Comparative Evaluation of The Marginal Sealing Ability of Fuji VII and Concise as Pit and Fissure Sealants.

10. Van Meerbeek B., Inoue S., Perdigao., Lambrechts P., Vanherle G. Enamel and dentin adhesion. In: Summit J,B., Robbin J,W., Schwartz R,S., Fundamental of Operative Dentistry A Contemporary Approach. $3^{\text {rded }}$ Quintessence. Chicago. Pp183, 2006

11. Reddy VR, Chowdhary N, Mukunda KS, Kavyarani BS, Pradeep MC. Retention of resin-based filled and unfilled pit and fissure sealant: a comparative clinical study. Contemporary Clinical Dentistry. 2015:6:1823

12. Hofmann N, Just N, Haller B, Hugo B, Klaiber B. The Effect of glass ionomer cement or composite resin bases on restoration of cuspal stiffness of endodontically treated premolars in vitro. Clin Oral Investig. 1998 Jun;2(2):77-83 